\title{
Treatment of Urinary Tract Infection during Pregnancy
}

\section{Abdullah Ahmad Basheer Alghamdi}

College of Medicine, Umm Al-Qura University, Saudi Arabia

*Corresponding author: Name Abdullah Ahmad Basheer Alghamdi, E-Mail: dr.expert333@gmail.com

\begin{abstract}
Introduction: Pharmacotherapeutic treatment strategies of urinary tract infections (UTIs) in pregnancy needs legitimate diagnostic investigation and comprehensive knowledge of antimicrobial medications. This review aiming at obtaining the evidence about the effectiveness of antibiotic treatment for UTI among pregnant women that evaluated by included randomized controlled trials.

Methods: An Electronic search was conducted in Medline and Researchgate databases using simple search terms include (Pregnan* AND Infection AND Treatment). The search of the literature, after exclusion of irrelevant, duplicated and review studies, revealed 8 studies met the inclusion criteria.

Results: Most of the included studies used cephalosporins family of antibiotics. The cure rate of ceftibuten was $95.2 \%$ compared to $90 \%$ in fosfomycin. A cure rate of $96 \%$ after treatment by ceftriaxone and $94 \%$ after administration of cephazolin were reported. When gentamycin plus ampicillin used for the treatment of UTIs a cure rate of $93 \%$ was reported. Conclusions: This review found high effectiveness and cure rate of the antibiotics used in treatment of UTIs, however the recurrence rate varied between studied antibiotics. Nitrofurantoin and intravenous antibiotics reported very low recurrence rate in comparison to fosfomycin and cephazolin with a clinically significant recurrence rate.
\end{abstract}

Keywords: Urinary Tract, Infections, Treatment, Antibiotics, Pregnancy.

\section{INTRODUCTION}

A definition UTIs is "the augmentation and multiplication of bacteria in the urinary tract," while the presence of bacteria in a collected urine sample is known as bacteriuria. Although all women are at risk to the advancement of UTIs, pregnant ladies are at higher risk than non-pregnant as a result of anatomical and hormonal differences which lead to ureteral dilatation and urinary stasis ${ }^{(\mathbf{1})}$. The hormonal changes that associated with pregnancy may elevate the chance of getting UTIs include progesterone-mediated ureteral and vesicular smooth muscle relaxation ${ }^{(2)}$.

As pregnancy continued, from the sixth week to 22th to 24th week, around $90 \%$ of pregnant women infected by ureteral dilatation, which will continue to labor (pregnancy hydronephrosis) ${ }^{(3)}$. Elevated volume of bladder and reduced tone of bladder, along with reduced tone of ureters, lead to ureterovesical reflux and elevated urinary stasis ${ }^{(4)}$. Urinary tract infections, including pyelonephritis, are the most frequent health issues during pregnancy ${ }^{(5)}$. They occur in $17 \%$ to $20 \%$ of pregnancies. Pyelonephritis is the most frequent acute bacterial infection that contributes to perinatal and maternal inconveniences like premature labor, infants with low birth weight, fetal mortality, preeclampsia, pregnancy-initiated hypertension, anemia, thrombocytopenia, and transient renalinadequacy (6). Enterobacteriaceae contribute to $90 \%$ of UTIs and the most effective antibiotics used are $\begin{array}{lcc}\text { Nitrofurantoin, } & \text { Cefazolin, } & \text { Cephalexin, } \\ \text { Ceftriaxone, } & \text { and } & \text { Gentamicin. }\end{array}$ Pharmacotherapeutic treatment strategies of UTIs in pregnancy needs legitimate diagnostic investigation and comprehensive knowledge of antimicrobial medications to guarantee best maternal outcome, ensure wellbeing to the fetus, and avert drawbacks that lead to huge morbidity and mortality in both the woman and her fetus ${ }^{(7)}$.

Thu, schedule bacterial culture and antibiotic sensitivity test of mid-stream urine samples of pregnant ladies and other patients are recommended to be measured before the provision of the medications for the management of UTIs ${ }^{(8)}$. In this manner, development of uncommon microbial resistance among these strains could effortless be recognized, and thus, helped in better treatment and management of those contaminated by these bacteria ${ }^{(9)}$. This review aiming at obtaining the evidence about the effectiveness of antibiotic treatment for UTI among pregnant women that evaluated by included randomized controlled trials.

\section{METHODS}

Electronic search was conducted in Medline and Researchgate databases using simple search terms include (Pregnan* AND Infection AND Treatment). The search of the literature, after exclusion of irrelevant, duplicated and review studies, revealed 8 studies met the inclusion criteria. The relevant data were extracted from these articles using data extraction 
sheet. Information about sample size, mean age of patients, the pregnancy trimester when treatment started, investigation of UTIs, symptoms of UTIs, antibiotic used for treatment infection, and the success rate of treatment.

The study was done after approval of ethical board of Umm Al-Qura University.

\section{RESULTS}

The search of the literature, after exclusion of irrelevant, duplicated and review studies, revealed 8 studies met the inclusion criteria. Included studies aimed to determine, from the best available evidence from randomized controlled trials (RCTs), which treatment is most effective for UTIs during pregnancy in terms of cure rates, recurrent infection, preterm delivery, premature rupture of membranes, admission to neonatal intensive care unit, need for change of antibiotic and incidence of prolonged pyrexia ${ }^{(5,10-14)}$.

The number of patients recruited ranged from 41 pregnant women in the study by Krcmery $\boldsymbol{e t} \boldsymbol{a l} .{ }^{(5)}$ to 179 in the study by Wing $\boldsymbol{e t}$ $\boldsymbol{a l} .^{(\mathbf{1 4})}$. The total number of pregnant women in the included studies was 927. Only one study reported a mean age of the pregnant women which was $(22.5 \pm 6.1)$ years old ${ }^{(13)}$. The reporting of pregnancy trimester in which treatment started found in four studies ${ }^{(\mathbf{1 0 - 1 3}, 15)}$.

In regard to antibiotic treatment for UTIs among pregnant women, most of the included studies used cephalosporins family of antibiotics $(5$, 10-14). However, the nitrofurantoin plus penicillin family used only by Calderon-Jaimes et $\boldsymbol{a l} .{ }^{(16)}$ for the treatment of urinary tract infection. Concerning effectiveness of antibiotics in the treatment of urinary tract infection, a cure rate of ceftibuten was found $95.2 \%$ compared to $90 \%$ in fosfomycin ${ }^{(5)}$. A cure rate of $96 \%$ after treatment by ceftriaxone and $94 \%$ after administration of cephazolin were reported ${ }^{(\mathbf{1 3})}$. When gentamycin plus ampicillin used for the treatment of UTIs a cure rate of 93\% was reported. The recurrence rate of UTIs was $4.76 \%$ with ceftibutin and $10 \%$ with fosfomycin ${ }^{(5)}$, while a recurrence rate of $0.16 \%$ and 0.9 was reported in nitrofurantoin, and intravenous antibiotics respectively ${ }^{(\mathbf{1 1})}$. The recurrence rtae in a study of Wing et al. ${ }^{(14)}$ was $5 \%$ with gentamycin plus ampicillin, $8 \%$ with cephazolin, and 5\% with ceftriaxone. Regarding reported secondary outcomes to the UTIs, $10 \%$ of women suffered pre-term delivery ${ }^{(\mathbf{1 4})}$.

Table 1: Summary of the findings

\begin{tabular}{|c|c|c|c|c|c|c|c|}
\hline Study & $\begin{array}{l}\text { Sample } \\
\text { size }\end{array}$ & $\begin{array}{c}\text { Time } \\
\text { when } \\
\text { treatment } \\
\text { started }\end{array}$ & $\begin{array}{l}\text { Types of } \\
\text { UTIs }\end{array}$ & Symptoms & $\begin{array}{l}\text { Antibiotic used } \\
\text { for treatment of } \\
\text { UTIs }\end{array}$ & Cure rate & $\begin{array}{l}\text { Other important } \\
\text { outcomes }\end{array}$ \\
\hline $\begin{array}{l}\text { Krcmery } \\
\text { et al. }\end{array}$ & $\begin{array}{c}41 \\
\text { pregnant } \\
\text { women }\end{array}$ & $\begin{array}{c}\text { Not } \\
\text { reported }\end{array}$ & $\begin{array}{l}\text { Acute } \\
\text { cystitis }\end{array}$ & $\begin{array}{l}\text { Symptoms } \\
\text { of lower UTI } \\
\text { (dysuria, } \\
\text { urgency, } \\
\text { frequency, and } \\
\text { suprapubic } \\
\text { pain) }\end{array}$ & $\begin{array}{l}\text { Fosfomycin, } \\
\text { trometamol, and } \\
\text { ceftibuten }\end{array}$ & \begin{tabular}{|l}
\multicolumn{1}{|c}{ Cure rate } \\
(sterile urine or \\
growth < 103 \\
CFU/ml) \\
$(20 / 21(95.2 \%)$ \\
vs $18 / 20$ \\
$(90.0 \%)$ \\
\end{tabular} & \begin{tabular}{|l}
\multicolumn{1}{c}{$\begin{array}{c}\text { Persistence } \\
\text { (growth of }\end{array}$} \\
original bacterial \\
strain $>=103$ \\
CFU/ml) $(1 / 21$ \\
$(4.76 \%)$ vs $2 / 20$ \\
$(10 \%)$
\end{tabular} \\
\hline $\begin{array}{l}\text { Brost } \\
\text { et al. }\end{array}$ & $\begin{array}{c}\mathbf{6 7} \\
\text { pregnant } \\
\text { women }\end{array}$ & $\begin{array}{l}22 \text { weeks } \\
\text { of } \\
\text { gestation }\end{array}$ & $\begin{array}{l}\text { Pyelo- } \\
\text { nephritis }\end{array}$ & $\begin{array}{l}\text { Symptoms } \\
\text { of oral } \\
\text { temperature of } \\
38^{\circ} \mathrm{C} \text { or } \\
\text { greater, } \\
\text { costovertebral } \\
\text { angle } \\
\text { tenderness. }\end{array}$ & $\begin{array}{l}\text { Intravenous } \\
\text { cephazolin only } \\
\text { or cephazolin } \\
\text { plus gentamicin } \\
\text { or cephazolin } \\
\text { plus other } \\
\text { antibiotic or } \\
\text { ampicillin plus } \\
\text { gentamicin or } \\
\text { other antibiotic } \\
\text { study group } \\
\text { received } \\
\text { nitrofurantoin } \\
\text { The control group } \\
\text { received no } \\
\text { further oral } \\
\text { antibiotic therapy }\end{array}$ & $\begin{array}{c}\text { Cure rate in } \\
\text { intravenous } \\
\text { antibiotics plus } \\
\text { nitrofurantoin } \\
\text { cure rate }=94 \%, \\
\text { in antibiotics } \\
\text { only }=87 \% \text {. }\end{array}$ & $\begin{array}{l}\text { Recurrent } \\
\text { infection in } \\
\text { intravenous } \\
\text { antibiotics plus } \\
\text { nitrofurantoin } \\
=16 \% \text { and in } \\
\text { intravenous } \\
\text { antibiotics only } \\
=9 \%\end{array}$ \\
\hline
\end{tabular}




\begin{tabular}{|c|c|c|c|c|c|c|c|}
\hline $\begin{array}{l}\text { Sanchez- } \\
\text { Ramos } \\
\text { et al. }{ }^{(13)}\end{array}$ & $\begin{array}{c}178 \\
\text { pregnant } \\
\text { women }\end{array}$ & $\begin{array}{c}23.6 \text { to } \\
24.1 \\
\text { weeks of } \\
\text { gestation }\end{array}$ & $\begin{array}{l}\text { Pyelon- } \\
\text { Ephritis } \\
\text { E.coli }\end{array}$ & $\begin{array}{l}\text { Febrile patients } \\
\text { (temperature of } \\
2100.4 " \mathrm{~F} \text { ) } \\
\text { with chills and } \\
\text { costovertebral } \\
\text { angle } \\
\text { tenderness }\end{array}$ & $\begin{array}{l}\text { Ceftriaxone } \\
\text { versus } \\
\text { Cefazoline }\end{array}$ & $\begin{array}{c}\text { Cure rates } \\
\text { (ceftriaxone } \\
96 \%, \\
\text { cefazolin 94\%) }\end{array}$ & $\begin{array}{l}\text { Recurrent } \\
\text { pyelonephritis } \\
\text { (ceftriaxone } \\
48 \% \text {, cephazolin } \\
66 \% \text { ) and preterm } \\
\text { delivery } \\
\text { (ceftriaxone } 10 \% \text {, } \\
\text { cephazolin 9\%) }\end{array}$ \\
\hline $\begin{array}{l}\text { Ahmadinejad } \\
\text { and } \\
\begin{array}{c}\text { Hantooshzadeh } \\
\text { 10) }\end{array}\end{array}$ & $\begin{array}{c}128 \\
\text { pregnant } \\
\text { women }\end{array}$ & $\begin{array}{l}24 \text { weeks } \\
\text { of } \\
\text { gestation }\end{array}$ & $\begin{array}{c}\text { Acute } \\
\text { pyelonep } \\
\text { hritis }\end{array}$ & Not reported & $\begin{array}{l}\text { patient ceftriaxone } \\
\text { ersus inpatient } \\
\text { ceftriaxone }\end{array}$ & $\begin{array}{c}\text { Cure rate of } \\
\text { nitial treatment } \\
\text { (inpatient= } \\
86 \% \text { ) } \\
\text { (outpatient } \\
=94 \% \text { ) }\end{array}$ & $\begin{array}{c}\text { Recurrent } \\
\text { pyelonephritis } \\
\text { (Inpatient= 11\%), } \\
\text { (outpatient= } \\
25 \% \text { ). } \\
\text { Preterm delivery } \\
\text { (inpatient }=19 \% \text { ) } \\
\text { (outpatient }=13 \% \text { ) }\end{array}$ \\
\hline $\begin{array}{l}\text { Ovalle } \\
\text { et al. }{ }^{(12)}\end{array}$ & $\begin{array}{c}111 \\
\text { pregnant } \\
\text { women }\end{array}$ & $\begin{array}{l}\text { Between } \\
12 \text { and } 34 \\
\text { weeks of } \\
\text { gestation }\end{array}$ & $\begin{array}{c}\text { Acute } \\
\text { pyelo- } \\
\text { nephritis }\end{array}$ & $\begin{array}{l}\text { Fever greater } \\
\text { than } 38^{\circ} \mathrm{C} \\
\text { chills, low } \\
\text { back pain }\end{array}$ & $\begin{array}{l}\text { Cephradine } \\
\text { Cefuroxime }\end{array}$ & $\begin{array}{l}\text { CFX is a more } \\
\text { efficient } \\
\text { therapy that } \\
\text { CPD, with } \\
\text { similar costs }\end{array}$ & $\begin{array}{l}\text { Microbiological } \\
\text { cure rate, clinical } \\
\text { cure rate, } \\
\text { recurrent } \\
\text { infection, } \\
\text { bacteriological } \\
\text { failure } \\
\text { rate, clinical cure } \\
\text { failure }\end{array}$ \\
\hline $\begin{array}{l}\text { Calderón } \\
\text { et al. }^{(16)}\end{array}$ & $\begin{array}{c}103 \\
\text { pregnant } \\
\text { women }\end{array}$ & $\begin{array}{c}\text { Not } \\
\text { reported }\end{array}$ & $\begin{array}{c}\text { Acute } \\
\text { cysto- } \\
\text { urethritis }\end{array}$ & $\begin{array}{l}\text { Symptoms of } \\
\text { dysuria, } \\
\text { frequency, } \\
\text { suprapelvic } \\
\text { pain or } \\
\text { tenderness }\end{array}$ & $\begin{array}{l}\text { Nitrofurantoin } \\
\text { versus } \\
\text { ampicillin }\end{array}$ & $\begin{array}{l}\text { Both regimens } \\
\text { showed similar } \\
\text { effectiveness } \\
\text { with regard to } \\
\text { cure rates, } \\
\text { recurrence } \\
\text { and treatment } \\
\text { failure }\end{array}$ & $\begin{array}{c}\text { Postpartum } \\
\text { outcomes } \\
\text { from each group } \\
\text { were not } \\
\text { presented }\end{array}$ \\
\hline $\begin{array}{l}\text { Wing } \\
\text { et al. }\end{array}$ & $\begin{array}{c}179 \\
\text { pregnant } \\
\text { women }\end{array}$ & $\begin{array}{c}\text { Earlier } \\
\text { than } \\
24 \text { weeks } \\
\text { of } \\
\text { gestation }\end{array}$ & $\begin{array}{l}\text { Pyelo- } \\
\text { nephritis }\end{array}$ & $\begin{array}{l}\text { Fever, and } \\
\text { costovertebral } \\
\text { angle } \\
\text { tenderness }\end{array}$ & $\begin{array}{l}\text { Ampicillin with } \\
\text { gentamicin versus } \\
\text { cephazolin } \\
\text { Versus ceftriaxone } \\
\text { and cephalexin }\end{array}$ & $\begin{array}{l}\text { Cure rates in } \\
\text { ampicillin } \\
\text { plus } \\
\text { gentamicin= } \\
93 \%, \text { in } \\
\text { cephazolin= } \\
94.8 \%, \text { in } \\
\text { ceftriaxone= } \\
16 \%) ;\end{array}$ & $\begin{array}{c}\text { Recurrent } \\
\text { pyelonephritis in } \\
\text { ampicillin plus } \\
\text { gentamicin=5\%, } \\
\text { in cephazolin=8\%, } \\
\text { ceftriaxone }=5 \%\end{array}$ \\
\hline $\begin{array}{l}\text { Millar } \\
\text { et al. }{ }^{(15)}\end{array}$ & $\begin{array}{c}120 \\
\text { pregnant } \\
\text { women }\end{array}$ & $\begin{array}{l}24 \text { weeks } \\
\text { of } \\
\text { gestation }\end{array}$ & $\begin{array}{l}\text { Pyelo- } \\
\text { nephritis }\end{array}$ & $\begin{array}{l}\text { Fever, flank } \\
\text { pain, or } \\
\text { costovertebral } \\
\text { angle } \\
\text { tenderness. }\end{array}$ & $\begin{array}{l}\text { Ceftriaxone and } \\
\text { cephalexin } \\
\text { compared in } \\
\text { outpatient and } \\
\text { inpatient } \\
\text { administration. }\end{array}$ & $\begin{array}{c}\text { Cure rates in } \\
\text { outpatients= } \\
95 \%, \text { in } \\
\text { inpatients= } \\
88 \% .\end{array}$ & $\begin{array}{c}\text { Recurrent } \\
\text { pyelonephritis rate } \\
\text { in inpatients=5\%, } \\
\text { and in } \\
\text { outpatients }=5 \% .\end{array}$ \\
\hline
\end{tabular}

\section{DISCUSSION}

This review aimed to determine the effectiveness of the treatment of symptomatic UTIs during pregnancy in terms of cure rates, recurrent infection, and incidence of preterm delivery. Eight randomized controlled trials were

included, where the intention was to allocate participants randomly to one of at least two alternative treatments for any symptomatic urinary tract infection. The critical appraisal of the included studies revealed that all included trials have small sample size $(<180)$ to detect significance differences between different treatment options. It is important to take into account that, in equivalence trials, failure to detect a difference does not imply equivalence between both treatments. Equivalence trials generally need to be larger than trials aimed to show that one treatment is better than other, because differences are 
expected to be small, and therefore, bigger numbers are needed to increase statistical power for detection of any significant difference ${ }^{(3)}$. In all of the included studies, sample sizes were insufficient to detect at least a $10 \%$ difference in cure rates between $95 \%$ and $85 \%$, which was considered the principal outcome for the review. To detect such difference, it would have been necessary to recruit at least 137 patients in each group, not taking into account dropouts and losses to follow-up ${ }^{(5)}$. In addition, the critical appraisal showed liability of selection bias in a study of Ovalle et $\boldsymbol{a l} .^{(\mathbf{1 2})}$ and unclear risk of bias related to alocation sequence in 3 studies $(\mathbf{5}, \mathbf{1 0}, \mathbf{1 1})$, which would signicantly undermine the validity of conclusion made by these trials.

Finally the included studies were heterogeneous and in comparable in terms of antibiotics used for the treatment, their efficacy, route of administration, tolerability and side effects which fail to detect evidence of inferiority, data from nonpregnant women should be included which may be useful for decision-making in the absence of adequate data from pregnant women, but it is very important to take into account the quite different pharmacodynamics of some drugs during pregnancy in order to gather more information on comparative efficacy of different antibiotics used for symptomatic UTIs ${ }^{(7)}$. Most studies found a cure rate ranged between $90 \%$ - 96\% of antibiotics such as ceftibuten, fosfomycin, ceftriaxone, cephazolin, gentamycin and ampicillin. However, a wide variation was reported in the recurrence rate of UTIs. It ranged from $0.16 \%$ to $0.9 \%$ in nitrofurantoin and intravenous antibiotics to $5 \%$ with gentamycin, ampicillin, and ceftriaxone to $8 \%$ and $10 \%$ in fosfomycin and cephazolin. This high recurrence rates can be attributed to the reduction in immunity status of pregnant women ${ }^{(9)}$.

\section{CONCLUSION}

This review found high effectiveness and cure rate of the antibiotics used in treatment of UTIs, however the recurrence rate varied between studied antibiotics. Nitrofurantoin and intravenous antibiotics reported very low recurrence rate in comparison to fosfomycin and cephazolin with a clinically significant recurrence rate. The lack of primary data with good quality and appropriate sample size, it is not possible to draw reliable conclusions on which is the best class, route or regimen of antibiotic to treat symptomatic UTIs during pregnancy. This review could not show that one treatment regimen is better than another.

\section{REFERENCES}

1.Kamienski M (2012): Treatments for symptomatic urinary tract infections during pregnancy. Int $\mathrm{J}$ Evid Based Healthc., 10(4):415-416.

2.Lee JB and Neild GH (2007): Urinary tract infection. Medicine, 35(8):423-8.

3.Andriole VT, and Patterson TF (1991): Epidemiology, natural history, and management of urinary tract infections in pregnancy. Med Clin North Am., 75(2):35973.

4.Beydoun SN (1985): Morphologic changes in the renal tract in pregnancy. Clin ObstetGynecol., 28(2):249-56.

5.Krcmery S, Hromec J, and Demesova D (2001): Treatment of lower urinary tract infection in pregnancy. Int J Antimicrob Agents, 17(4):279-82.

6.Alcaraz CLD, and Reyes-Paredes N (2006): Enfermedades renales y embarazo. Revista del Hospital General Dr Manuel Gea González, 7(2):82-9.

7.Kariuki S, Revathi G, Corkill J, Kiiru J, Mwituria J, Mirza N et al. (2007): Escherichia coli from communityacquired urinary tract infections resistant to fluoroquinolones and extended-spectrum beta-lactams. J Infect Dev Ctries., 1(03):257-62.

8.Salvatore S, Salvatore S, Cattoni E, Siesto G, Serati M, Sorice $P$ et al. (2011): Urinary tract infections in women. Eur J Obstet Gynecol Reprod Biol., 156(2):131-6.

9.Okonko I, Donbraye-Emmanuel O, Ijandipe L, Ogun A, Adedeji A, and Udeze A (2009): Antibiotics sensitivity and resistance patterns of uropathogens to nitrofurantoin and nalidixic acid in pregnant women with urinary tract infections in Ibadan, Nigeria. Middle-East J Sci Res., 4(2):105-9.

10.Ahmadinejad Z, and Hantooshzadeh S (2006): Outpatient treatment of acute pyelonephritis in pregnancy after 24 weeks. A randomised controlled trial. Clin Microbiol Infect., 12(2):132-137.

11.Brost BC, Campbell B, Stramm S, Eller D, and Newman RB (1996): Randomized clinical trial of antibiotic therapy for antenatal pyelonephritis. Infect Dis ObstetGynecol., 4(5):294-7.

12.Ovalle A, Martinez M, Wolff M, Cona E, Valderrama O, Villablanca E et al. (2000): Efficacy, safety and cost of cefuroxime compared with cephradine in the treatment of acute pyelonephritis during pregnancy. Rev Med Chil., 128(7):749-57.

13.Sanchez-Ramos L, McAlpine KJ, Adair CD, Kaunitz AM, Delke I, and Briones DK (1995): Pyelonephritis in pregnancy: once-a-day ceftriaxone versus multiple doses of cefazolin: a randomized, double-blind trial. Am J Obstet Gynecol., 172(1):129-33.

14. Wing D, Hendershott C, Debuque $L$, and Millar $L$ (1998): A randomized trial of three antibiotic regimens for the treatment of pyelonephritis in pregnancy. Obstet Gynecol., 92(2):249-53.

15. Millar LK, Wing DA, Paul RH, and Grimes DA (1995): Outpatient treatment of pyelonephritis in pregnancy: a randomized controlled trial. Obstet Gynecol., 86(4):560-4.

16.Calderón JE, Arredondo GJ, Olvera SJ, Echániz AG, Conde GC, Hernández NP (1989): Acute cystourethritis during pregnancy. Ginecol Obstet Mex., 5(1):57-63. 